\title{
Auxin polar transport in stamen formation and development: how many actors?
}

\author{
Maura Cardarelli ${ }^{1 *}$ and Valentina Cecchetti ${ }^{1,2}$ \\ 1 Istituto di Biologia, Medicina Molecolare e Nanotecnologie, CNR, Sapienza Università di Roma, Rome, Italy \\ 2 Dipartimento di Biologia e Biotecnologie, Sapienza Università di Roma, Rome, Italy
}

\author{
Edited by: \\ Lucia Colombo, University of Milan, \\ Italy \\ Reviewed by: \\ Yanhai Yin, lowa State University, \\ USA \\ Stefan De Folter, CINVESTAV-IPN, \\ Mexico \\ *Correspondence: \\ Maura Cardarelli, Istituto di \\ Biologia, Medicina Molecolare e \\ Nanotecnologie, CNR, Sapienza \\ Università di Roma, Piazzale Aldo \\ Moro 5, 00185 Rome, Italy \\ e-mail: maura.cardarelli@uniroma1.it
}

In flowering plants, proper development of stamens, the male reproductive organs, is required for successful sexual reproduction. In Arabidopsis thaliana normally six stamen primordia arise in the third whorl of floral organs and subsequently differentiate into stamen filaments and anthers, where male meiosis occurs, thus ending the early developmental phase. This early phase is followed by a late developmental phase, which consists of a rapid elongation of stamen filaments coordinated with anther dehiscence and pollen maturation, and terminates with mature pollen grain release at anthesis. Increasing evidence suggests that auxin transport is necessary for both early and late phases of stamen development. It has been shown that different members of PIN (PIN-FORMED) family are involved in the early phase, whereas members of both PIN and P-glycoproteins of the ABCB (PGP) transporter families are required during the late developmental phase. In this review we provide an overview of the increasing knowledge on auxin transporters involved in Arabidopsis stamen formation and development and we discuss their role and functional conservation across plant species.

Keywords: stamen development, auxin transport, Arabidopsis, dicots, monocots

\section{INTRODUCTION}

Stamens are the male reproductive structure of flowers and their function is to produce pollen grains, which house male gametes, and to release them at flower opening to allow plant reproduction. Male fertility results from sequential developmental events that involve an early phase of stamen formation and morphogenesis and a late phase that consists of pollen grain maturation, stamen filament elongation and anther dehiscence. In autogamous plants, such as Arabidopsis thaliana, stamen growth should be coordinated to pistil development to allow self-pollination. Alterations in stamen development lead to male sterile plants that can be utilized to generate hybrids useful for agronomic practice.

The plant hormone auxin, which is predominantly represented by indole-3-acetic acid (IAA), contributes to all aspects of plant development mainly through its differential distribution within plant tissues. Auxin concentration controls the expression of hundreds of genes by the ubiquitin-mediated pathway based on the interplay of two classes of transcription factors, auxin-response factors (ARFs) and Aux/IAA repressors (reviewed in Parry and Estelle, 2006). Local auxin concentration is the combined result of auxin biosynthesis and transport. The key enzymes involved in the main auxin biosynthetic pathway belong to YUC family of flavin monooxygenases -which consists of 11 YUC genes in Arabidopsis (reviewed in Zhao, 2012) and show distinct but partially overlapping expression patterns during diverse developmental programs. Differential distribution of synthesized auxin is mainly achieved by a polar cell-to-cell transport system (PAT), and this is unusual among phytohormones, given that polar transport has not been detected for any other signaling molecules (Benjamins and Scheres, 2008; Zažímalová et al., 2010). The protonated form IAAH can either enter cells passively due to the low $\mathrm{pH}$ in cell walls or can be pumped into cells by influx carrier of the AUX/LAX family (Swarup and Péret, 2012). In contrast, due to the higher $\mathrm{pH}$ in the cytosol, auxin cannot cross the membrane and the anion IAA ${ }^{-}$can only exit from cells by efflux carriers. Proteins of the PIN-FORMED (PIN) family are the main group of efflux carriers with a polar cellular distribution (Gälweiler et al., 1998; Friml et al., 2003; Paponov et al., 2005; Friml, 2010). PINs carriers can be divided in a large-loop and a short-loop subgroups. Large-loop PINs (PIN1, PIN2, PIN3, PIN4, and PIN7), characterized by a large hydrophilic loop, localize to the plasma membrane, and direct auxin transport across those membranes where they are localized. Short-loop PINs (PIN5, PIN6, and PIN8) are devoided of the large hydrophilic loop (Paponov et al., 2005), and are not recruited to the plasma membrane but are proposed to regulate auxin homeostasis between the cytoplasm and endoplasmic reticulum (ER) (Mravec et al., 2009; Wabnik et al., 2011). Recently, a family of seven PIN-LIKES proteins (PILS) localized in the ER has been described as regulators of intracellular auxin homeostasis (Barbez et al., 2012). In addition to the PINs, the $\mathrm{ABCB} /$ multidrug resistance/P-glycoproteins ( $\mathrm{ABCB} / \mathrm{MDR} / \mathrm{PGP})$ are ATP Binding Cassette subfamily $\mathrm{B}$ (ABCB) transporters associated with polar auxin transport mainly in auxin efflux. Of the subfamily, at least five members have been reported to mediate cellular transport of auxin (or auxin derivatives) coordinately with PIN proteins (Blakeslee et al., 2005; Titapiwatanakun et al., 2008; Zažímalová et al., 2010; Peer et al., 2011). 
Different research findings have provided a role for PAT in early and late phases of stamen development. In this review, we discuss the present knowledge on the contribution of auxin transport to Arabidopsis stamen formation and development and functional conservation of different auxin transporters in other species.

\section{STAMEN STRUCTURE}

Arabidopsis has four long and two short stamens-collectively termed androecium - each of which consists of two morphologically distinct parts: the filament and the anther. The filament, which serves as a conduit for water and nutrients, has a simple radialized structure with a single vascular strand. It provides structural support to the anther and anchors the stamen to the receptacle, the stem to which the floral organs are attached (Figure 1A). The anther contains the reproductive and non-reproductive tissues that contribute to pollen maturation, protection, and release, so that the self-pollination process can occur into the flower. The anther has a bilaterally symmetrical four lobed structure and each lobe contains a microsporangium (pollen sac) in which pollen develops in chambers known as locules. The anther lobes are laterally attached to a vascular bundle by a contiguous parenchymatous tissue called connective, and the vascular bundle is continuous with the vasculature of the filament (Sanders et al., 1999; Ma, 2005; Murmu et al., 2010). A transverse section of a differentiated anther is butterfly-shaped and each of the four locules is surrounded by four distinct, concentric layers of cells with special tasks in stamen development: an inner wall layer called the tapetum-adjacent to the sporogenous cells-necessary for pollen nourishment and development; the thin layer termed middle layer, whose function has also been associated to pollen development; the endothecium, a subepidermal tissue required for anther opening and pollen release; and the outer epidermis, that covers and protects all the microsporangia (Figure 1B) (Esau, 1977; Pacini et al., 1985; Goldberg et al., 1993; Scott et al., 2004; Wilson et al., 2011).

\section{STAMEN DEVELOPMENT}

Flower morphogenesis begins when the inflorescence meristem produces floral meristems on its flanks. Floral organ primordia arise from floral meristems in a precise number and are arranged in concentric whorls forming the basic flower structure with four types of organs: sepals, petals, stamens, and carpels (Figure 1C). Floral organ primordia identity is determined by the combined action of four classes of floral organ identity genes (A, B, C, and $\mathrm{E})$, according to the genetic ABCE model (reviewed in Wellmer et al., 2013). Stamen formation occurs in the third whorl due to the combination of BCE class gene activity.

The entire stamen developmental process in Arabidopsis is divided into an early and a late phase. During the early phase, primordia arise and histospecification, morphogenesis and microsporogenesis occur (Figure 1D). During the late phase,
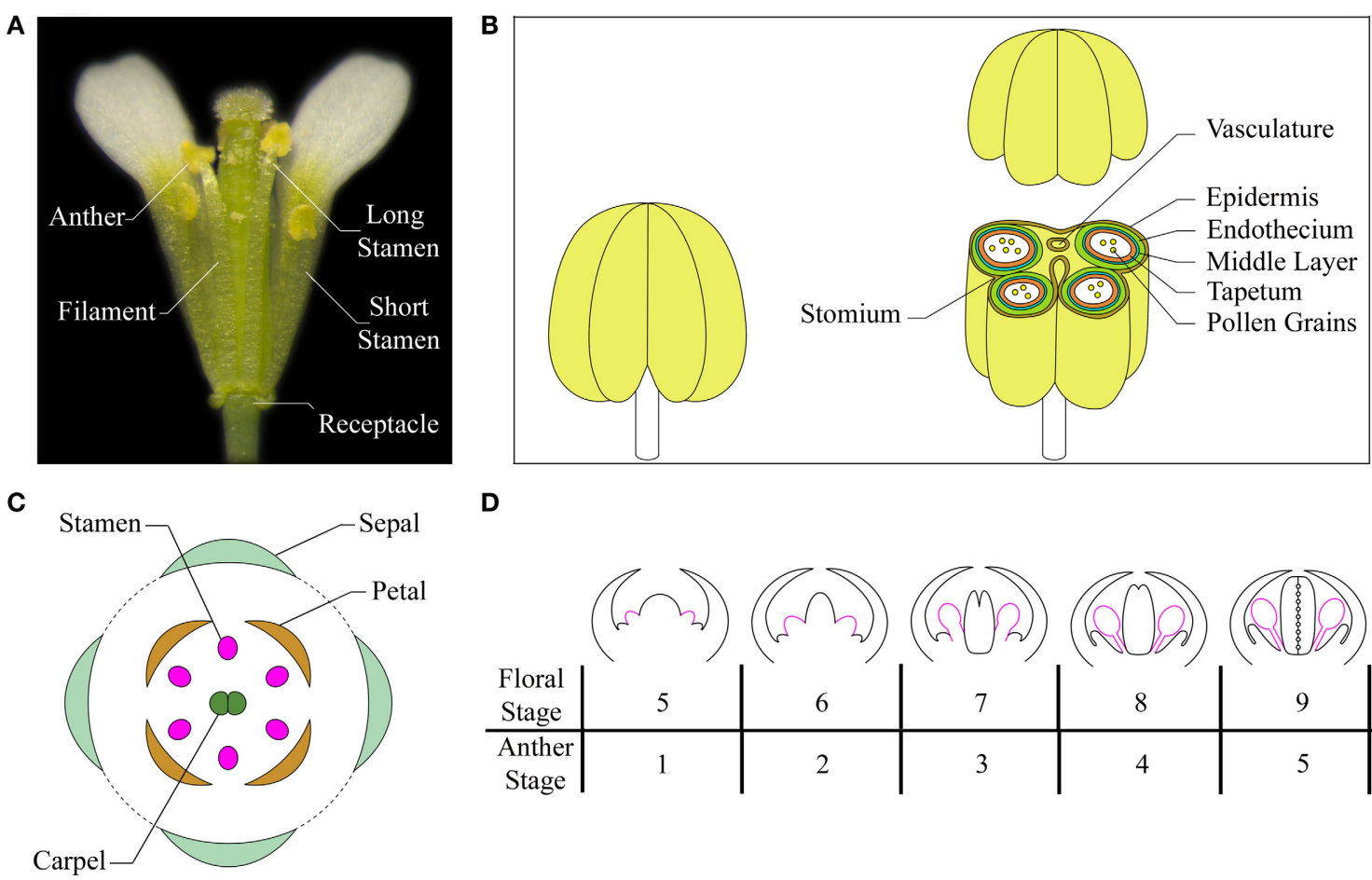

D

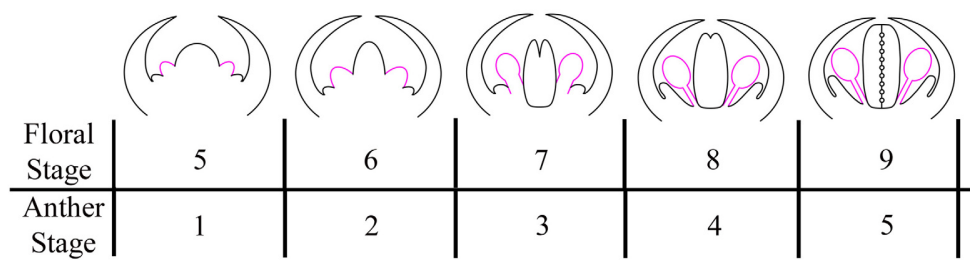

FIGURE 1 | The Arabidopsis stamen. (A) A mature flower at anthesis showing short and long stamens (with the removal of some petals and sepals for visualization). (B) Cartoon of a stamen at a stage after meiosis (left) and of the stamen transverse section, at the level of the anther, with differentiated tissues indicated in different colors (right). Based on Sanders et al. (2000), Jia et al. (2008), Smyth (2010). (C) A diagram showing different floral organs with stamens depicted in pink. Based on Bowman (1994), Whipple et al. (2004). (D) Schematic representation of early development of stamens in Arabidopsis flowers at floral stages from 5 to 9/anther stages from 1 to 5 . Stamens are depicted in pink. Based on Ito et al. (2007), Alvarez-Buylla et al. (2010). 


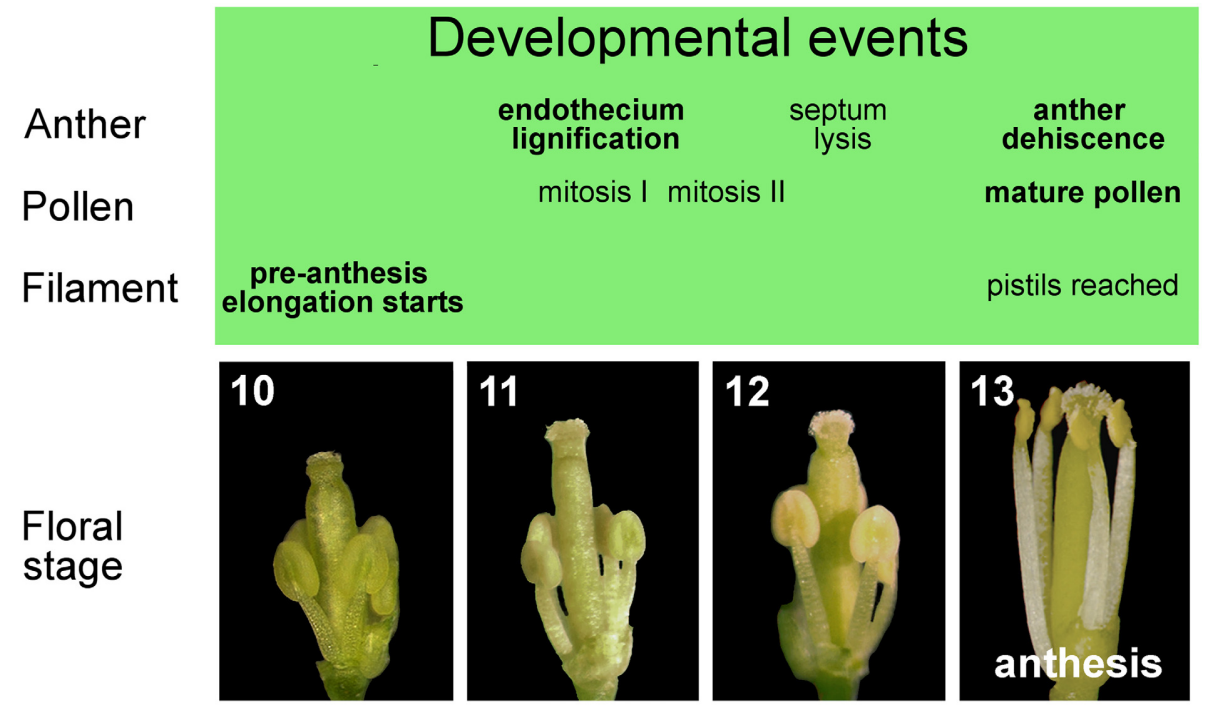

FIGURE 2 | Late development of stamens in flower buds from stages $\mathbf{1 0}$ to $\mathbf{1 3}$. Main events in the development of anther, pollen, and filament occurring in stamens during late flower development.

microspores differentiate into pollen grains, stamen filaments elongate to reach the pistil, anthers enlarge and a tissue degeneration process occurs inside the anther, leading to anther dehiscence and pollen grain release at flower opening (Figure 2) (Goldberg et al., 1993; Cecchetti et al., 2008; Feng and Dickinson, 2010).

In Arabidopsis, six stamen primordia appear, due to divisions in the L1, L2, and L3 layers of the floral meristem during stage 5 of flower development (as defined by Smyth et al., 1990; Bowman, 1994) or anther stage 1 (as defined by Sanders et al., 1999), with the long stamens primordia arising first (Figure 1D). Stamen primordia appear at the same time as the petal primordia, after the appearance of sepal, but before gynoecium primordia. From floral stage 5 to 9 (or /anther stage 1-5) divisions in the L1 layer form the stamen epidermis, while L3 cells divide to form connective and vasculature tissues. Periclinal divisions of L2 cells, called archesporial cells, form primary parietal and primary sporogenous cells that give rise to the four radially symmetrical microsporangia. By floral stage $7 /$ anther stage 3 , the regions that will give rise to the filament and the anther become distinct. At floral stage 8/anther stage 4 two larger abaxial anther locules and two smaller adaxial pair are visible and are separated by the connective tissue. Next, the primary parietal cells give rise to the three anther wall layers (tapetum, middle layer and endothecium), and the primary sporogenous cells develop into microspore mother cells (floral stage 8/anther stage 4). Mother cells go through meiosis to form a microspore tetrad, surrounded by a callose wall that isolates meiotic cells (floral stage 9/anther stage 5). Most of early stamen growth occurs at floral stage 9 mainly in the anther region, while only $20 \%$ of the total stamen length is due to the filament. By stage 9, the anther shows the characteristic four-lobed morphology and anther morphogenesis is complete (Figure 1D).

From floral stage 10 to 13 , late development occurs, which consists of three different developmental programs: pollen maturation, anther dehiscence and filament elongation. At the beginning of late development at floral stage 10/anther stage 8 , the callose wall surrounding the tetrads degenerates, leading to the release of individual microspores into the anther locules. The microspores then generate an exine wall, and become vacuolated at floral stage 10/anther stage 9. The first mitotic division of microspores occurs at floral stage 11/anther stage 10 and gives rise to bicellular pollen grains, while the second pollen mitotic division occurs at floral/anther stage 12, resulting in tricellular haploid pollen grains that are capable of germinating at anthesis (floral/anther stage 13) (Figure 2). The main developmental phases of anther dehiscence are: degeneration of the middle layer and tapetum at floral stage 11/anther stage 10; expansion of the endothecial layer followed by deposition of fibrous bands (wall thickenings) in endothecial (and connective) cells at floral/anther stage 11; degeneration of the septum - the cells separating the two locules-which generates a bilocular anther at floral/anther stage 12. The breakage of the stomium, a group of specialized epidermal cells, is the final event and occurs at anthesis-floral stage 13/anther stage 12 . The pre-anthesis growth of the stamen filament takes place from floral stage 10 to anthesis and is particularly rapid from stage $12-13$ due to cell elongation. At floral stage 13 (Figure 2), when flower opens, with petals bent outwards, stamens have reached the pistil, anther opening occurs, and the filaments continue to extend to allow the subsequent pollen deposition on the receptive stigma at floral stage 14 (Smyth et al., 1990; Bowman, 1994; Sanders et al., 1999; Scott et al., 2004; Cecchetti et al., 2008).

\section{AUXIN TRANSPORT AND THE EARLY PHASE OF STAMEN DEVELOPMENT STAMEN PRIMORDIA FORMATION}

In addition to floral meristem initiation, auxin controls the early phase of floral organ primordia formation and morphogenesis. 
Local auxin biosynthesis, transport, and signaling are all critical for stamen (and floral organs) initiation as a reduction in stamen number is observed in different classes of mutants. Single yuc4 mutant flowers -defective in the auxin biosynthetic gene YUC4- show one or two stamens, and few floral organs (Ståldal et al., 2012), while the yuclyuc4 double mutant flowers show only stamen-like structures and few outer whorl organs. This latter phenotype is rescued by the expression of the bacterial auxin biosynthetic gene iaaM under the control of the YUC1 promoter (Cheng et al., 2006; Krizek, 2011). Mutants defective in different AUXIN RESPONSE FACTOR (ARFs) genes such as ARF3/ETTIN or ARF5/MONOPTEROS, show flowers with reduced number of stamens, together with increased number of sepals and petals and abnormal gynoecia (Sessions et al., 1997), or few flowers with reduced number of stamens, together with less petals and a single carpel respectively (Przemeck et al., 1996). A reduced number of stamens, as well as no floral buds or flowers with no stamens, were first related to a decreased auxin transport, in plants cultured in the presence of different auxin transport inhibitors such as 1-naphthylphthalamic acid (NPA) (Okada et al., 1991; Reinhardt et al., 2000) and 2,3,5-triiodobenzoic acid (TIBA) (Thomson et al., 1973). These phenotypes strongly resembled those of mutants defective in the auxin polar transporter PIN1: the pin-1 strong mutant was unable to form flowers (Okada et al., 1991; Bennett et al., 1995; Gälweiler et al., 1998), while few flowers that fail to form stamens or flowers with a reduced number of stamens were observed in weaker alleles such as pin-3, pin4 , and pin-5, respectively. Similarly pid mutants, defective in the PINOID (PID) protein kinase that controls PIN1 polarity, show flowers with a range of defects that can include a pin-shaped inflorescence or alterations in stamen number (Bennett et al., 1995). In addition, mab4 mutants, defective in the enhancer of PID, MACCHI-BOU 4 (MAB4), show flowers with a reduced number of stamens (Treml et al., 2005; Furutani et al., 2007). Indeed, PIN1 and PID expression is high at the site of incipient stamens in young flowers (Christensen et al., 2000; Reinhardt et al., 2003). Other members of the PIN family seem also to be involved in stamen primordia formation; for example, pin3pin 7 double mutant flowers show no stamens, together with bear fused petals, and occasionally no sepals, suggesting a role for both PINs in stamen formation (Benková et al., 2003). On the other hand PIN6, one member of the short-loop PINs, promotes short stamen primordia formation, as the loss-of-function mutant pin6-2 lacks one or both short stamens (Bender et al., 2013). Benková et al. (2003) analyzed the auxin distribution during floral organ formation by monitoring the expression gradients of the auxin responsive element DR5, an indirect reporter of auxin accumulation in plant cells (Ulmasov et al., 1997; Michniewicz et al., 2007); DR5 expression reaches a maximum at the tip of primordia in all floral organs. Based on the correlation between PIN1 localization, DR5 gradients, and primordia formation, as well as on the interference in DR5 activity exerted by auxin efflux inhibitors, they proposed a model for all developing floral primordia. According to their model, floral organ primordia formation is dependent on apical auxin transport mediated by PIN-dependent efflux, which supplies auxin to the tip through the outer layer L1; in the inner layers, PINs transport auxin away from the tip through the primordium interior, giving rise to the provascular strands. This general model can also be applied to stamens, since van Mourik et al. (2012) showed that when stamen primordia arise-at the transition of stage 4 to 5 -DR5 signal peaks in a small group of cells in the central region of the floral meristem, where initiation of the 4 long stamen primordia occurs. DR5 signal is observed in L1 cells, in the cell layers below where provasculature is formed and in deeper layers where the provasculature of both petals and stamens develop. In addition, based on a simulation study of auxin transport through a growing floral meristem, van Mourik et al. (2012) proposed that sepals are initiated by the auxin maxima forming at the tip during early meristem outgrowth. Then the sepals direct the positions of the smaller auxin maxima associated with the petal, stamen, and carpel anlagens - the initial clustering of cells from which primordia develop.

PAT is also involved in the formation of boundaries between organ primordia, by regulating the expression of the CUC1 and CUC2 genes. The role of these genes is to inhibit the growth of cells at the boundaries between primordia to avoid organ fusion. As PID and CUC expression domains are overlapping in the boundary of cotyledon primordia, it has been suggested that PID, by promoting auxin transport, reduces the level of auxin at the boundary and increases it in the primordia during cotyledon formation (Furutani et al., 2004). This model can be also applied to stamens, as CUC1 is expressed in boundaries between stamen primordia at stage 5-6 of floral development (Takada et al., 2001). In agreement, in pid (Bennett et al., 1995) and mab4-1 (Furutani et al., 2007) mutant flowers, bifid stamens are frequently observed, with two filaments fused partly or completely along their length.

Apparently, $\mathrm{ABCB} / \mathrm{PGP}$ transporters have no effect on the formation of stamen primordia, as mutants defective in single $A B C B / P G P$ genes as well as the abcb1abcb19/pgp1pgp19 double mutants are not altered in the number of stamens. However, analysis of the triple pin1pgp1pgp19 mutant-which lacks PIN1 in addition to PGP1 and PGP19 - show partial rescue of the pin1 mutant phenotype and formation of few flowers (Blakeslee et al., 2007). In contrast the double pin1pgp19 is unable to form flowers. This suggests that the loss of $A B C B 1 / P G P 1$ is epistatic to $P I N 1$ in floral meristems, and that the partial restoration of flower formation could be due to ectopic auxin accumulation in the floral meristem. This effect is only exerted by $A B C B 1 / P G P 1$ loss in the pin1 background and suggests that $A B C B 1$, but not $A B C B 19$, contribute to floral organ primordial formation (Blakeslee et al., 2007). The role of auxin influx carriers in stamen primordia formation has not yet been clarified. It has been shown that aux 1 single mutant, defective in the influx carrier AUX1, show normal flower development without reduction in the number of stamens. However, mutations in $A U X 1$ and in its paralogs $L A X 1, L A X 2$, and $L A X 3$ lead to quadruple mutant flowers with an abnormal structure, showing defects in floral organ number and positioning (Bainbridge et al., 2008).

Taken together this data (summarized in Table 1) suggest that auxin, synthesized by YUC genes in young floral buds, is first transported directionally toward the tip of the primordium, where it reaches a maximum necessary for stamen primordia formation and then is transported basipetally to the interior of the 
Table 1 | Summary of the role in Arabidopsis stamen development of auxin-related genes.

\begin{tabular}{|c|c|c|c|c|c|}
\hline Gene(s) & Mutant(s) & Phenotype(s) & Gene function & $\begin{array}{l}\text { Stamen development } \\
\text { stages }\end{array}$ & Reference(s) \\
\hline PIN1 & $\begin{array}{l}\text { pin-3 } \\
\text { pin-4 } \\
\text { pin-5 }\end{array}$ & $\begin{array}{l}\text { No stamens } \\
\text { No stamens } \\
\text { Few stamens }\end{array}$ & Polar auxin efflux & $\begin{array}{l}\text { Long stamen primordia } \\
\text { formation }\end{array}$ & Bennett et al., 1995 \\
\hline $\begin{array}{l}\text { PIN3 } \\
\text { PIN7 }\end{array}$ & $\begin{array}{l}\text { pin3-5pin7-1 } \\
\text { double mutant }\end{array}$ & No stamens & Polar auxin efflux & $\begin{array}{l}\text { Long stamen primordia } \\
\text { formation }\end{array}$ & Benková et al., 2003 \\
\hline PIN6 & pin6-2 & $\begin{array}{l}\text { One or both short stamens } \\
\text { missing }\end{array}$ & $\begin{array}{l}\text { Intra-cellular auxin } \\
\text { homeostasis }\end{array}$ & $\begin{array}{l}\text { Short stamen primordia } \\
\text { formation }\end{array}$ & Bender et al., 2013 \\
\hline PINOID & $\begin{array}{l}\text { pid-1 } \\
\text { pid-2 } \\
\text { pid-8 }\end{array}$ & $\begin{array}{l}\text { Few stamens } \\
\text { Few stamens } \\
\text { Abnormal anthers }\end{array}$ & $\begin{array}{l}\text { Ser/Thr } \\
\text { Kinase, regulator of auxin } \\
\text { efflux }\end{array}$ & $\begin{array}{l}\text { Stamen primordia } \\
\text { formation } \\
\text { Stamen morphogenesis }\end{array}$ & Bennett et al., 1995 \\
\hline MACCHI-BOU 4 & mab4-1 & $\begin{array}{l}\text { Few stamens } \\
\text { Abnormal anthers }\end{array}$ & Enhancer of PINOID & $\begin{array}{l}\text { Stamen primordia } \\
\text { formation } \\
\text { Stamen morphogenesis }\end{array}$ & Furutani et al., 2007 \\
\hline PIN2 & eir1-4 & Shorter filaments & Polar auxin efflux & $\begin{array}{l}\text { Late stamen } \\
\text { development }\end{array}$ & Kim et al., 2013 \\
\hline$A P-2$ & $\begin{array}{l}a p 2 m-1 \\
a p 2 m-2\end{array}$ & $\begin{array}{l}\text { Shorter filaments } \\
\text { Defective pollen grains } \\
\text { Altered pollen tube } \\
\text { growth }\end{array}$ & $\begin{array}{l}\text { Clathrin-mediated } \\
\text { endocytosis } \\
\text { Regulator of PIN } \\
\text { localization }\end{array}$ & $\begin{array}{l}\text { Late stamen } \\
\text { development }\end{array}$ & Kim et al., 2013 \\
\hline PIN8 & pin8-1 & $\begin{array}{l}\text { Aborted or misshaped pollen } \\
\text { grains }\end{array}$ & $\begin{array}{l}\text { Intra-cellular auxin } \\
\text { homeostasis }\end{array}$ & $\begin{array}{l}\text { Late stamen } \\
\text { development }\end{array}$ & Ding et al., 2012 \\
\hline PIN5 & pin5-5 & Defective pollen grains & $\begin{array}{l}\text { Intra-cellular auxin } \\
\text { homeostasis }\end{array}$ & $\begin{array}{l}\text { Late stamen } \\
\text { development }\end{array}$ & Ding et al., 2012 \\
\hline $\begin{array}{l}A B C B 1 \\
A B C B 19\end{array}$ & $\begin{array}{l}\text { pgp1pgp19 } \\
\text { double mutant }\end{array}$ & $\begin{array}{l}\text { Shorter filaments } \\
\text { Early dehiscent anthers }\end{array}$ & $\begin{array}{l}\text { ABC transporters, Auxin } \\
\text { efflux } \\
\text { Mediators }\end{array}$ & $\begin{array}{l}\text { Late stamen } \\
\text { development }\end{array}$ & $\begin{array}{l}\text { Noh et al., } 2001 \\
\text { Cecchetti et al., } 2008\end{array}$ \\
\hline $\begin{array}{l}\text { YUC4 } \\
\text { YUC1 }\end{array}$ & $\begin{array}{l}\text { yuc4-1 } \\
\text { yuc1yuc4 } \\
\text { double mutant }\end{array}$ & $\begin{array}{l}\text { Few stamens } \\
\text { Stamen-like structures }\end{array}$ & Auxin biosynthesis & $\begin{array}{l}\text { Stamen primordia } \\
\text { formation }\end{array}$ & $\begin{array}{l}\text { Ståldal et al., } 2012 \\
\text { Cheng et al., } 2006\end{array}$ \\
\hline $\begin{array}{l}\text { YUC2 } \\
\text { YUC6 }\end{array}$ & $\begin{array}{l}\text { yuc2yuc6 } \\
\text { double mutant }\end{array}$ & $\begin{array}{l}\text { No pollen grains } \\
\text { No stamen elongation } \\
\text { Altered anther dehiscence }\end{array}$ & Auxin biosynthesis & $\begin{array}{l}\text { Late stamen } \\
\text { development }\end{array}$ & Cheng et al., 2006 \\
\hline $\begin{array}{l}\text { ARF5/ } \\
\text { MONOPTEROS }\end{array}$ & $\begin{array}{l}m p^{T 370} \\
m p^{G 92} \\
\text { gain-of-function } \\
m p^{a b n}\end{array}$ & $\begin{array}{l}\text { Few stamens } \\
\text { Few stamens } \\
\text { Indehiscent anthers }\end{array}$ & $\begin{array}{l}\text { Auxin response } \\
\text { Transcription factor }\end{array}$ & $\begin{array}{l}\text { Stamen primordia } \\
\text { formation } \\
\text { Late stamen } \\
\text { development }\end{array}$ & $\begin{array}{l}\text { Przemeck et al., } 1996 \\
\text { Przemeck et al., } 1996 \\
\text { Garrett et al., } 2012\end{array}$ \\
\hline $\begin{array}{l}\text { ARF3/ } \\
\text { ETTIN }\end{array}$ & ett-1 & Few stamens & $\begin{array}{l}\text { Auxin response } \\
\text { Transcription factor }\end{array}$ & $\begin{array}{l}\text { Stamen primordia } \\
\text { formation }\end{array}$ & Sessions et al., 1997 \\
\hline$A R F 17$ & $\operatorname{arf17}$ & $\begin{array}{l}\text { Altered pollen wall patterning } \\
\text { Altered pollen tube growth }\end{array}$ & $\begin{array}{l}\text { Auxin response } \\
\text { Transcription factor }\end{array}$ & $\begin{array}{l}\text { Late stamen } \\
\text { development }\end{array}$ & Yang et al., 2013 \\
\hline ARF2 & $m n t$ & $\begin{array}{l}\text { Altered stamen length } \\
\text { Shorter filaments }\end{array}$ & $\begin{array}{l}\text { Auxin response } \\
\text { Transcription factors }\end{array}$ & $\begin{array}{l}\text { Late stamen } \\
\text { development }\end{array}$ & Schruff et al., 2006 \\
\hline$A R F 1$ & $\begin{array}{l}\text { arf2-8 } \\
\text { arf1-5arf2-8 } \\
\text { double mutant }\end{array}$ & Shorter filaments & & & $\begin{array}{l}\text { Ellis et al., } 2005 \\
\text { Ellis et al., } 2005\end{array}$ \\
\hline
\end{tabular}


Table 1 | Continued

\begin{tabular}{|c|c|c|c|c|c|}
\hline Gene(s) & Mutant(s) & Phenotype(s) & Gene function & $\begin{array}{l}\text { Stamen development } \\
\text { stages }\end{array}$ & Reference(s) \\
\hline $\begin{array}{l}\text { ARF6 } \\
\text { ARF8 }\end{array}$ & $\begin{array}{l}\text { arf6-2arf8-3 } \\
\text { double mutant }\end{array}$ & $\begin{array}{l}\text { Short filaments } \\
\text { Indehiscent anthers }\end{array}$ & $\begin{array}{l}\text { Auxin response } \\
\text { Transcription factors }\end{array}$ & $\begin{array}{l}\text { Late stamen } \\
\text { development }\end{array}$ & Nagpal et al., 2005 \\
\hline $\begin{array}{l}\text { TIR1 } \\
\text { AFB1 } \\
\text { AFB2 } \\
\text { AFB3 }\end{array}$ & $\begin{array}{l}\text { tir1afb1afb2afb3 } \\
\text { quad mutant }\end{array}$ & $\begin{array}{l}\text { Shorter filaments } \\
\text { Early dehiscent anthers } \\
\text { Precocious pollen maturation }\end{array}$ & Auxin receptors & $\begin{array}{l}\text { Late stamen } \\
\text { development }\end{array}$ & Cecchetti et al., 2008 \\
\hline $\begin{array}{l}\text { IDD14 } \\
\text { IDD15 } \\
\text { IDD16 }\end{array}$ & $\begin{array}{l}\text { idd } \\
\text { triple mutant }\end{array}$ & $\begin{array}{l}\text { Asynchronous elongation of } \\
\text { stamen filaments and styles }\end{array}$ & $\begin{array}{l}\text { Transcription factors } \\
\text { Regulators of the } \\
\text { expression of YUC5 and } \\
\text { PIN1 }\end{array}$ & $\begin{array}{l}\text { Late stamen } \\
\text { development }\end{array}$ & Cui et al., 2013 \\
\hline
\end{tabular}

A

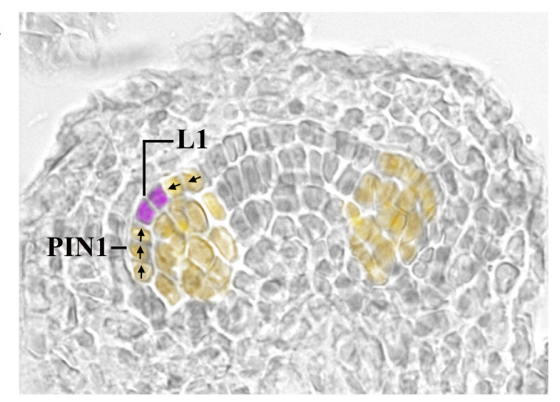

B

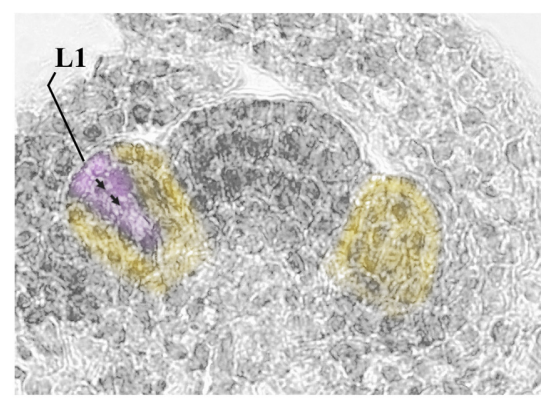

C
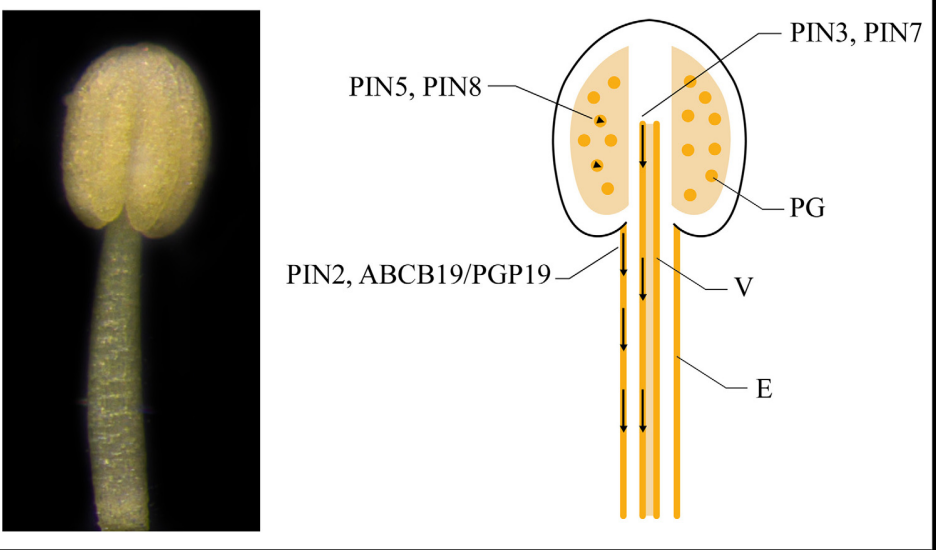

FIGURE 3 | Auxin transport in stamens during early and late developmental stages. (A,B) Stamen primordia (yellow) at stage 5 (A) and 6 (B) of flower development. Places of auxin accumulation are depicted in purple. Presumptive routes of auxin transport are depicted by black arrows. (C) A stamen at stage 11 of flower development (left). Cartoon of a longitudinal section of a stamen at stage 11 of flower development (right). Basipetal auxin transport in the stamen filament is depicted by black arrows in epidermal cells and vascular tissue. Arrowheads indicate regulation of auxin homeostasis inside pollen grains. E, epidermal cells; L1, L1 layer; PG, pollen grains; $V$, vascular tissue. primordium as shown in the model in Figures 3A,B. Auxin transport is mainly carried out by PIN1, with a contribution of PIN3 and PIN7 in the 4 long stamens formation, which still needs to be clearly defined. Further studies are needed to determine the role of $\mathrm{ABCB} 1$ which functions primarily in minimizing apoplastic reflux in apical tissues with high auxin (Geisler and Murphy, 2006) and that of influx carriers AUX1, LAX1, LAX2, and LAX3, which could concentrate auxin in the cytoplasm of cells of the L1 layer, thus preventing auxin diffusion from the L1 (Bainbridge et al., 2008).

\section{STAMEN MORPHOGENESIS}

Auxin is synthesized also in the subsequent stages of stamen morphogenesis when different auxin biosynthetic genes such as YUC2 
and YUC6 are expressed. Indeed, detectable auxin levels, as measured by gas chromatography analysis, can be observed in anthers at stages 8 and 9, although DR5 activity is visible only later, at the beginning of late development (Cheng et al., 2006; Cecchetti et al., 2008).

Scattered evidence suggests the involvement of auxin transport in stamen morphogenesis. As described by Bennett et al. (1995) pid anthers are often abnormal, with locules occurring in various numbers and shapes while pid pollen is fertile. This data suggests that auxin transporters, which are target of PID phosphorylation are required for stamen morphogenesis but are not involved in microspore formation and development (see below). In addition, it has been recently shown that PIN6 is expressed in anthers at stage 8 of flower development/anther stage 4 , as detected by GUS staining of proPIN6:GUS flowers. This would suggest that PIN6, in addition to its role in short stamen formation (see above), could also be necessary for the formation of long stamens (Bender et al., 2013).

\section{AUXIN TRANSPORT AND DIFFERENT PROCESSES OF LATE STAMEN DEVELOPMENT}

Auxin is a key regulator of the developmental processes occurring late in stamen development: anther dehiscence, pollen maturation, and pre-anthesis filament elongation.

Intense DR5:GUS expression has been observed in stamens at different stages of late development (Aloni et al., 2006; Feng et al., 2006). At the end of meiosis (floral stage 10/anther stage 9) DR5 activity is observed in anther sporophytic tissues surrounding the locules (tapetum, middle layer, and endothecium), as well as in microspores and in vascular cells of the anther and the filament. At floral stage/anther stage 11 DR5 activity was mainly detectable in the remnants of tapetum, in immature pollen grains, and in the anther-filament vasculature, whereas it is no longer detectable at floral stage/anther stage 12 after septum lysis (Cecchetti et al., 2008). By measuring IAA concentration in Arabidopsis anthers at various developmental stages it was shown that DR5 activity corresponds to changes in free IAA concentrations (Cecchetti et al., 2013). Further, all three developmental processes are severely altered in tirlafb multiple mutants, which lack the auxin receptors TIR1 and AFB (Cecchetti et al., 2008). Accordingly, ARF mutants show stamen development defects: arf6arf8 double mutants fail to elongate stamen filaments at anthesis and show indehiscent anthers, while arf2 single mutant flowers exhibit altered stamen length (Ellis et al., 2005; Nagpal et al., 2005; Schruff et al., 2006). Recently it has been shown that $m p^{\text {abn }}$ the gain-of-function mutant of ARF5/ MONOPTEROS, shows indehiscent anthers (Garrett et al., 2012). In addition arf17 single mutant flowers are defective specifically in pollen wall patterning and pollen tube growth (Yang et al., 2013). A peak in auxin concentration is observed at the beginning of late development, but auxin synthesis probably starts before, at premeiotic and meiotic stages, as suggested by the expression of YUC2 and YUC6 genes in stamens (Cecchetti et al., 2013). Accordingly, in yuc2yuc6 double mutant flowers, no pollen grains are formed and stamen elongation does not occur, leading to sterile flowers, and indicating a block in late stamen development, which can in fact be rescued by expression of the bacterial auxin biosynthesis gene iaaM under the control of YUC6 promoter (Cheng et al., 2006).

The observed auxin accumulation at the beginning of late development is not due to the transport of auxin through the filament to anthers. Indeed, blocking transport by NPA treatment of DR5:GUS flowers before late development (at premeiotic and meiotic stages), did not impair DR5 activity in stamens; similarly, in anthers severed at a premeiotic stage from DR5:GUS flower buds and matured in vitro, GUS staining was not altered and was comparable to control DR5:GUS anthers (Cecchetti et al., 2008). However, increasing evidence shows that PAT not only is fundamental for stamen filament elongation, but also has a role in pollen development and anther dehiscence. NPA-treated flowers showed shorter filaments if treated at floral stage/anther stage 11 when, as judged from DR5 activity, auxin has already built up in stamens (Cecchetti et al., 2008). Furthermore, pgp1pgp19 double mutant flowers have reduced stamen filament elongation (Noh et al., 2001). Accordingly, ABCB19/PGP19 is expressed in stamen epidermal cells, where it functions primarily in basipetal auxin transport from the stamen filament apical region to the basal side (Blakeslee et al., 2007; Titapiwatanakun and Murphy, 2009). Recently, a polar localization of PIN2 in the stamen filaments has been observed by Kim et al. (2013); eir1-4 plants, which have a loss-of-function mutation in PIN2, showed defects in filament elongation and a reduced DR5 activity in anthers and in basal sides of the filaments. The authors also show that the shorter filament phenotype was observed in $30 \%$ of eirl-4 flowers, compared to $90 \%$ of ap $2 m-1$ flowers, defective in the adaptor protein complex 2 (AP-2), which regulates polar distribution of PINs. This raises the possibility that auxin levels are also modulated by other PIN proteins in addition to PIN2 in stamens (Kim et al., 2013). Some indirect evidence in support to this hypothesis comes from studies on a family of nine early auxin-responsive genes, called SMALL AUXIN UP RNAs (SAURs). In particular, GUS staining was observed in the vascular tissues of SAUR63:GUS stamens and reduced expression of SAUR63 causes a short stamen phenotype whereas lines overexpressing SAUR63 showed long stamen filaments. Quite interestingly, when a SAUR63:GUS translational fusion construct was expressed in pgp1pgp19 plants, their flowers had longer stamen filaments than $p g p 1 p g p 19$ flowers. In contrast, when SAUR63:GUS was expressed in pin3-4pin7-2 double mutant plants, their filament length was comparable to that of pin3-4pin7-2 double mutant flowers (Chae et al., 2012). Thus, SAUR63 could promote auxin-induced growth of stamen filament during late development via PIN3 and PIN7, but not via ABCB1/PGP1 and ABCB19/PGP19, possibly acting on perivascular cells to direct auxin flux.

The involvement of auxin transport in pollen development mediated by short-loop PINs has been reported in different papers. According to transcriptomic data (Honys and Twell, 2004; Pina et al., 2005; Wang et al., 2008), PIN8 and PIN6 are expressed during pollen development at high and low levels, respectively and, in agreement, pins mutation resulted in aborted or misshaped pollen grains, though at very low frequencies (Ding et al., 2012). Moreover, an antagonistic/compensatory activity of PIN8 and PIN5 has been suggested by Ding et al. (2012) who has showed that pin 5 loss of function mutants displayed the same 
percentage of defective pollen grains as pin8, whereas pin5pin8 double mutants could rescue the pollen morphology defects observed in the single mutants. Some others transporters can be involved in pollen maturation and germination as suggested by transcriptomic data: PILS5, which encodes for a protein localized in the ER like PIN5, PIN6, and PIN8, is widely expressed during pollen development, from bicellular to mature pollen, as well as during pollen germination according to Dal Bosco et al. (2012b). In addition a low level of expression of the large-loop PIN genes, PIN1, PIN2 and PIN4 has been reported in mature pollen grains (Dal Bosco et al., 2012a; Kim et al., 2013). Because ap2m-1 flowers have both an altered PINs polar distribution, and an impaired pollen germination, it is possible that specific polar PINs, might be involved in maintaining auxin homeostasis in pollen tube elongation (Kim et al., 2013). Further experiment should shed light on their molecular identity.

Little data has been reported on the role of auxin transporters on the anther dehiscence process. However, Cecchetti et al. (2008) showed that pgp1pgp19 flowers, in addition to short stamen filaments, also exhibit a small percentage of early dehiscent anthers. On the other hand, treatment with NPA of flower buds at floral stage 11 resulted in 15-20\% of indehiscent anthers at stage 13 .

Taken together, this data, summarized in Table 1 indicates that the basipetal auxin transport from the filament apex to the basis is responsible for proper stamen filament elongation during late stamen development (Cecchetti et al., 2008; Titapiwatanakun and Murphy, 2009). Different transporters are involved in auxin transport in epidermal cells such as PIN2, ABCB19/PGP19 and $\mathrm{ABCB} 1 / \mathrm{PGP} 1$ or in perivascular tissues such as PIN3 and PIN7 as shown in the model described in Figure 3C.

A main role in pollen maturation seems to be provided by ERlocalized PINs, such as PIN8 and PIN5, and possibly PILS5. These proteins should be able to transport IAA from the cytoplasm to the ER, where enzymes involved in conjugation/hydrolysis and storage of IAA are accumulated, thus affecting auxin concentration. As it is known that developing and germinating pollen grains have high auxin levels, it is possible that the ER-localized PINs regulate the release of auxin from the internal stores in the ER to control pollen development and to drive auxin-mediated pollen tube elongation. Data on large-loop PINs suggests that auxin is also provided to pollen grains by polar transport. Two models have been proposed. Auxin could be transported to developing pollen grains from tapetum cells, which are known to accumulate auxin at the beginning of late development, as proposed by Aloni et al. (2006). Alternatively, according to Feng et al. (2006), auxin could be transported to developing pollen grains from the stamen filament.

In contrast, the current available data does not allow the construction of a model on auxin distribution in different tissues during the anther dehiscence process, but does suggests that auxin transport through $\mathrm{ABCB} 1$ and $\mathrm{ABCB} 19$ regulates the timing of anther dehiscence (Cecchetti et al., 2008).

Stamen and carpel development need to be coordinated to allow self-fertilization at anthesis. The arf1 and arf2 single mutants show defects in both stamen filament and in the length of style-the gynoecium portion, which connects the stigma with the ovary. These defects could be related to auxin transport, as auxin distribution seems to be finely regulated during late development in the style (Girin et al., 2011). Thus, it is possible that auxin transport during late floral stages allows the coordination of style and stamen elongation. Indeed, it has been recently shown that flowers from the triple mutant $i d d$, defective in the INDETERMINATE DOMAIN (IDD) transcription factor genes IDD14, IDD15, and IDD16, exhibits infertile siliques resulted from the asynchronous elongation of stamen filaments and styles. The transcription of $A U X 1, P I N 1, A B C B 1$, and $A B C B 4$ is severely reduced in the idd mutant, and the IDD proteins could directly bind to the promoter regions of PIN1 to activate its expression (Cui et al., 2013).

\section{THE ROLE OF AUXIN TRANSPORT DURING EARLY AND LATE PHASES OF STAMEN DEVELOPMENT IN OTHER SPECIES}

Additional information is emerging regarding the role of auxin transport in early and late phases of stamen development in other angiosperms, mainly by determining the function of orthologs in other species of Arabidopsis genes already known to be involved in auxin synthesis, polar transport, and signal transduction. Summarized below are the most abundant information on PAT in dicots and monocots.

\section{DICOTS}

As described earlier for Arabidopsis, dicot flowers have in common arrangement in four whorls with an outermost whorl composed of sepals and the second one of petals. The third and the fourth whorls contain the reproductive organs, stamen, and carpel respectively.

The tomato (Solanum lycopersicum) floral system is distinguished from that of Arabidopsis as tomato flowers contain five sepals, alternating with five petals, five anti-sepalous stamens (stamen attachment is in line with the sepals) and two fused carpels are observed. Stamens are fused together to form a cylinder that surrounds the style.

Tomato has long served as a major model for fruit development and information on the role of auxin on stamen development mostly derives from experiments that were not directly focused on male reproductive organs. For example, downregulation of SIIAA9, a member of the Aux/IAA transcription factor gene family encoding a negative auxin response regulator, gives rise to a parthenocarpic fruit, but also causes undeveloped stamens. In agreement, SIIAA9 mRNA is visible in stamen floral meristem, in emerging stamens and during subsequent development as well as in other floral organs (Wang et al., 2005). Similarly SITIR1, homologous to Arabidopsis AtTIR1, is expressed in stamens in all developmental stages before anthesis (Ren et al., 2011). SlFLOOZY (ToFZY), the putative tomato orthologous gene of AtYUC4, has been identified and it is expressed in immature flowers. In addition tomato genome contains many genes that encode flavin monooxygenases-like proteins, similar to the situation observed for Arabidopsis YUC genes (ExpósitoRodríguez et al., 2007). This data suggest that most genes involved in auxin biosynthesis and signaling are conserved in tomato.

Indirect evidence on the role of auxin transport in tomato stamen formation comes from the culture of tomato apices 
on NPA-containing medium that results in naked pin1-like inflorescences (Reinhardt et al., 2000). Among the 10 homologs of Arabidopsis PIN genes (SlPIN1-10) found in tomato, SIPIN4 is the most expressed, although at a low level, in stamens during flower development up to the anthesis. In agreement $\mathrm{P}_{35 \mathrm{~S}}$ :SlPIN4 ${ }^{\mathrm{RNAi}}$ flowers show alterations in stamen morphogenesis and development together with abnormal sepals and parthenocarpic fruit development (Mounet et al., 2012). This evidence suggests that SIPIN4 might be the major PIN player in regulating both stamen morphogenesis and development. An additional role for auxin transport during early and late stamen development has been suggested by phenotypical analysis of polycotyledon mutants ( $p o c$ ) (Madishetty et al., 2006). The poc loss-of-function mutation causes an increase in the basipetal auxin transport in stems and due to several abnormalities in floral organs, possibly in flowers. In particular, poc mutants have an increased number of stamens characterized by the lack of the typical fusion of filaments. Late developmental processes are also altered, since poc anthers lack dehiscence and stamens are shorter, possibly due a reduction in epidermal cells length (Al-Hammadi et al., 2003). Future studies will be necessary to confirm and expand this evidence that suggest a fundamental role for PAT in early and late stamen development.

Medicago (Medicago truncatula) is a model species for the study of flower morphogenesis in legumes. The main difference in Medicago stamen development compared to Arabidopsis is the existence of four common primordia from which petals and stamens differentiate. Medicago flowers are organized in four whorls and show a pentamerous arrangement of sepals and petals, ten stamens and a central carpel. Nine stamen filaments are joined in a staminal tube around the carpel, and the tenth, the vexillary stamen filament at the adaxial position, is free standing.

Medicago YUC-like genes MtYUC1, MtYUC2, and MtYUC3 have been found by sequence homology search but no functional data has been reported yet (Tivendale et al., 2010). However, a gradient of DR5 activity with a maximum of auxin at the tips of floral organs has been detected and is required for proper development of primordia (Zhou et al., 2011).

Medicago has more PIN and LAX genes than Arabidopsis (8 PINs and 4 AUX/LAXs in Arabidopsis vs. 9 PINs and 5 LAXs in Medicago) (Schnabel and Frugoli, 2004). Phylogenetic analysis indicated that MtPIN4, MtPIN5, and MtPIN10 belong to a small cluster and are all homologous to the Arabidopsis PIN1. MtPIN10, which shows 65\% amino acid identity with AtPIN1, indeed seems to have a role in stamen development but, in contrast to Arabidopsis pin1 mutants, mtpin10 mutants develop flowers. However these flowers have unfused stamens, also reduced in number, together with altered sepals and carpels and are sterile. This data suggests a role for PAT, and in particular for MtPIN10, in stamen (and other floral organs) primordia formation and separation (Peng and Chen, 2011; Zhou et al., 2011).

\section{MONOCOTS}

The Poaceae (grasses) family, one of the largest flowering plant families in angiosperms, includes many economically important crops such as maize and rice. The grass inflorescence is composed of different types of branches, including a specialized branch called spikelet. The spikelet is a special unit of the inflorescence and forms one to several florets, depending on the species. In the floret, floral organs such as perianth organs, carpels, and stamens are formed. In grasses, different types of meristem, such as the inflorescence meristem (IM), the branch meristem (BM), the spikelet pair meristem (SPM, present only in some grasses), the spikelet meristem (SM) and the floral meristem (FM), are responsible for the complex development of inflorescences and flowers.

Maize (Zea Mays) is monoecious and the male inflorescence, the tassel, situated at the shoot apex, consists of a main spike with several long lateral branches at the base. Normal tassels produce florets whose meristems give rise to a lemma and palea (outer whorl structures derived from bracts or sepals), two lodicules (derived from petals), and three stamens.

Auxin has a main role in maize stamen primordia formation as the single mutant spil, defective in a flavin monooxygenase with similarity to the YUC genes, show a reduced number of stamens. In addition, auxin maxima (visualized by DR5:RFP), are clearly associated with the initiation of floral organ primordia, including stamen primordia in tassel (Gallavotti et al., 2008a).

A role for auxin transport in stamen primordia formation is suggested by the phenotype of the mutant bif2, which is defective in a serine/ threonine protein kinase co-orthologous to PID, and which has florets with no floral organs at all, or reduced stamen numbers. In addition, when stamens arise, they are deformed, suggesting that bif2 can be also involved in the subsequent stamen developmental phases (McSteen and Hake, 2001). Similar to the mutation in bif2, Bif1, a classical semidominant mutation of maize, causes fewer florets and a reduced number of stamens in most florets. Many of the phenotypes seen in Bif1 (and bif2) mutants are also seen in plants treated with auxin transport inhibitors (Wu and McSteen, 2007) and, consistently, Bif1 mutation causes a reduction of auxin transport. This data suggests a role for Bif1 in regulating auxin transport (Barazesh and McSteen, 2008). BIF2 has been shown to be able to phosphorylate ZmPIN1a, one out of the three homologs of PIN1 in maize, called ZmPIN1a, -b and -c. ZmPIN1a driven by the AtPIN1 promoter can rescue most, but not all, defects of the Arabidopsis pin1-3 mutant, as some flowers still show the lack of stamens. This data suggests an at least partial conservation in polar auxin transport mechanisms between maize and Arabidopsis (Gallavotti et al., 2008b). Basal ZmPINs (ZmPIN1a, ZmPIN1b, and ZmPIN1c) localization has been shown in different plant organ tissues such as coleoptile cells (Nishimura and Koshiba, 2010). ZmPIN1s seem to be localized in the L1/epidermal outer layer and in the inner tissues of male inflorescence meristem, according to Carraro et al. (2006), although this data has not been confirmed by subsequent analysis (Forestan and Varotto, 2012). However its localization during stamen primordia formation still needs to be determined. Thus, further experiments are necessary to shed further light on the role of auxin transport in stamen formation. Furthermore, very recently a previously uncharacterized ZmPIN protein most closely related to PIN1 that is present in all flowering plants but lost in the Brassicaceae, including Arabidopsis, has been identified in maize, called Sister-of-PIN1 (SoPIN1). SoPIN1 
expression is evident in the L1 and L2 layers of spikelet meristems (O'Connor et al., 2014). In addition one more member of PIN1 cluster (named ZmPIN1d), one gene homologous to AtPIN2 (ZmPIN2), three orthologs of PIN5 (ZmPIN5a-c), one gene paired with AtPIN8 ( $Z m P I N 8)$, and three monocot-specific PINs (ZmPIN9, ZmPIN10a, and ZmPIN10b), 2 ABCB-like genes, $Z m A B C B 1 / B R 2$ and three orthologs of AtABCB19 (ZmABCB2, $Z m A B C B 10 \_1$, and $\left.Z m A B C B 10 \_2\right)$ have recently been identified (Knöller et al., 2010; Forestan and Varotto, 2012; Forestan et al., 2012).

In conclusion, it is not possible to infer from the available data to what extent auxin transport is involved in stamen primordia formation/development in maize. Future experiments should focus on the identification of all players that can contribute to stamen morphology and growth in order to propose a unified model of stamen development.

Rice (Oryza sativa) inflorescence architecture is quite different from that of maize, as flowers are hermaphrodite, and one rice spikelet has only one floret surrounded by a pair of empty glumes (corresponding to sepals). In addition, rice florets have an asymmetric structure with five types of floral organs: one lemma and one palea in the first outer whorl, two lodicules in the second whorl, six stamens in the third whorl and one pistil with two stigmas in the fourth innermost whorl.

At least seven $Y U C$-like genes have been found in rice, and it is very likely that these OsYUCs are also redundantly involved in IAA biosynthesis in different organs. OsYUC1 is the gene most closely related to AtYUC1 and AtYUC4 and is the ortholog of $\mathrm{ZmSPI1}$. Although OsYUC1 is expressed in developing flowers, a phenotypical analysis of flowers from the available OsYUC1 antisense or overexpressing plants is still lacking (Yamamoto et al., 2007). However, the fact that $t d d 1$ plants, defective in a protein which catalyses the first step of the Trp biosynthesis pathway, show reduced IAA content and flowers with altered stamen number and sometimes malformed stamens, suggests that auxin — and, possibly, auxin transport_-controls stamen development in rice as well (Sazuka et al., 2009). Indeed, overexpression of the single rice PID ortholog, OsPID, alters the number of floral organs and leads to a reduction of stamen number and an increase of the number of stigmas. In addition, developing stamens show an overall abnormal morphology, a phenotype that could be phenocopied by treatment with NPA (Morita and Kyozuka, 2007). Rice has also three PIN1 orthologs (OsPIN1, OsPIN1b, and OsPIN1c). Functional analysis has been reported only for OsPIN1 and revealed that OsPIN1 knockdown plants do not have the characteristic pin phenotype. However, OsPIN1 is highly expressed in flowers, and in particular in stamen filaments and at the junction region between anther and filament during late development ( $\mathrm{Xu}$ et al., 2005). Similarly OsPIN3t, which shows high aminoacid sequence identity to AtPIN3, is expressed in mature anthers (Zhang et al., 2012). Phenotypic analysis of double and triple OsPIN1 mutant flowers could shed light on the role of these transporters in stamen development.

Taken together, this data suggest, but are far from being conclusive, a role for auxin transport in stamen primordia formation such as in maize, and also in stamen filament elongation during late flower development.

\section{CONCLUSIONS}

The data reported in this review, (summarized in Table 1) clearly show the fundamental role of PAT in the formation of stamen primordia in Arabidopsis. The general model proposed by Benková et al. (2003) on floral organ primordia formation, and supported by van Mourik et al. (2012) for stamens, is mainly based on the direction of auxin flow mediated by PIN1 that creates the auxin maxima in the L1 layer - at stage 5 of flower development-and an auxin gradient in the subsequent stages due to basipetal auxin transport. The integrated model is presented in Figures 3A,B. However, additional work is necessary to assess PIN3 and PIN7 role in stamen primordia formation and to establish the contribution of other efflux carriers such as $\mathrm{ABCB} / \mathrm{PGP}$ proteins as well as that of influx carriers. This will shed light also on the direction of auxin transport during subsequent developmental stages leading to stamen morphogenesis.

Auxin transport also appears to regulate later developmental processes that require coordination with each other and with gynoecium development. Basipetal auxin transport-exerted by different members of large-loop PINs and ABCB/PGP familiesthrough epidermal and vascular cells regulates stamen filament elongation is described in the model presented in Figure 3C. However, whether other auxin transporters are involved in filament elongation and whether PAT coordinates late development of male and female reproductive organs remains to be investigated. Current data also indicate that different ER-localized PINs, which affect auxin concentration, regulate pollen development and germination. However the role of large-loop PINs as well as that of $\mathrm{ABCB}$ proteins in regulating the timing of anther dehiscence in these latter processes is still elusive.

The mechanisms of auxin transport, together with those of auxin biosynthesis and signal transduction, appear conserved in dicots and monocots. Alignment of AtPIN1 and other dicotspecific orthologs, with monocot members of the PIN1 family indicates that all PIN1 genes share a common overall structure. However the monocot PIN family is wider and more divergent than the dicot one, with three or four genes homologous to one single Arabidopsis PIN gene. In addition, the overall expression profile of the PIN genes is different between Arabidopsis and maize: while in Arabidopsis each PIN has a specific expression domain, many $Z m P I N$ genes are simultaneously expressed in the same organ or tissue (Forestan et al., 2012). In addition, PID-like genes have been also identified in maize and rice (McSteen and Hake, 2001; Morita and Kyozuka, 2007). Furthermore, orthologs of AtABCB1/PGP1 and AtABCB19/PGP19 have also been identified in maize (Knöller et al., 2010), sorghum and rice (Shen et al., 2010) but no data is currently available on their role in flower and stamen development.

In summary, the available data suggests that auxin transportdependent mechanisms are required for proper stamen development and in particular for stamen primordia formation in dicots as well as in monocots. However to propose a model of more general validity all actors need to be identified to gain a full understanding of how the auxin gradient during stamen development is established. Furthermore more work directly focused on stamen growth is necessary to understand the involvement of PAT in different processes of early and late stamen development. 


\section{ACKNOWLEDGMENTS}

We would like to thank prof. Giovanna Serino for critical reading of the manuscript. Research in our lab is funded by a grant to Maura Cardarelli, from the Italian Ministry of Foreign Affairs (Direzione Generale per la Promozione del Sistema Paese).

\section{REFERENCES}

Al-Hammadi, A. S., Sreelakshmi, Y., Negi, S., Siddiqi, I., and Sharma, R. (2003). The polycotyledon mutant of tomato shows enhanced polar auxin transport. Plant Physiol. 133, 113-125. doi: 10.1104/pp.103.025478

Aloni, R., Langhans, M., Aloni, E., and Ullrich, C. I. (2006). Role of auxin in regulating Arabidopsis flower development. Planta 223, 315-328. doi: 10.1007/s00425-005-0088-9

Alvarez-Buylla, E. R., Benítez, M., Corvera-Poiré, A., Cador, Á. C., de Folter, S., Gamboa de Buen, A., et al. (2010). Flower development. Arabidopsis Book 8:e0127. doi: 10.1199/tab.0127

Bainbridge, K., Guyomarc'h, S., Bayer, E., Swarup, R., Bennett, M., Mandel, T., et al. (2008). Auxin influx carriers stabilize phyllotactic patterning. Genes Dev. 22, 810-823. doi: 10.1101/gad.462608

Barazesh, S., and McSteen, P. (2008). Barren inflorescencel functions in organogenesis during vegetative and inflorescence development in maize. Genetics 179, 389-401. doi: 10.1534/genetics.107.084079

Barbez, E., Kubeš, M., Rolcík, J., Béziat, C., Pencík, A., Wang, B., et al. (2012). A novel putative auxin carrier family regulates intracellular auxin homeostasis in plants. Nature 485, 119-122. doi: 10.1038/nature11001

Bender, R. L., Fekete, M. L., Klinkenberg, P. M., Hampton, M., Bauer, B., Malecha, M., et al. (2013). PIN6 is required for nectary auxin response and short stamen development. Plant J. 74, 893-904. doi: 10.1111/tpj.12184

Benjamins, R., and Scheres, B. (2008). Auxin: the looping star in plant development. Annu. Rev. Plant Biol. 59, 443-465. doi: 10.1146/annurev.arplant.58. 032806.103805

Benková, E., Michniewicz, M., Sauer, M., Teichmann, T., Seifertová, D., Jürgens, G., et al. (2003). Cell 115, 591-602. doi: 10.1016/S0092-8674(03)00924-3

Bennett, S. R. M., Alvarez, J., Bossinger, G., and Smyth, D. R. (1995). Morphogenesis in pinoid mutants of Arabidopsis thaliana. Plant J. 8, 505-520. doi: 10.1046/j.1365-313X.1995.8040505.x

Blakeslee, J. J., Peer, W. A., and Murphy, A. S. (2005). Auxin transport. Curr. Opin. Plant Biol. 8, 494-500. doi: 10.1093/mp/ssr034

Blakeslee, J. J., Bandyopadhyay, A., Lee, O. R., Mravec, J., Titapiwatanakun, B., Sauer, M., et al. (2007). Interactions among PIN-FORMED and Pglycoprotein auxin transporters in Arabidopsis. Plant Cell 19, 131-147. doi: 10.1105/tpc.106.040782

Bowman, J. L. (1994). Arabidopsis: An Atlas of Morphology and Development. New York, NY: Springer-Verlag.

Carraro, N., Forestan, C., Canova, S., Traas, J., and Varotto, S. (2006). ZmPIN1a and $\mathrm{ZmPIN} 1 \mathrm{~b}$ encode two novel putative candidates for polar auxin transport and plant architecture determination of maize. Plant Physiol. 142, 254-264. doi: 10.1104/pp.106.080119

Cecchetti, V., Altamura, M. M., Brunetti, P., Petrocelli, V., Falasca, G., Ljung, K., et al. (2013). Auxin controls Arabidopsis anther dehiscence by regulating endothecium lignification and jasmonic acid biosynthesis. Plant J. 74, 411-422. doi: $10.1111 /$ tpj.12130

Cecchetti, V., Altamura, M. M., Falasca, G., Costantino, P., and Cardarelli, M. (2008). Auxin regulates Arabidopsis anther dehiscence, pollen maturation, and filament elongation. Plant Cell 20, 1760-1774. doi: 10.1105/tpc.107.057570

Chae, K., Isaacs, C. G., Reeves, P. H., Maloney, G. S., Muday, G. K., Nagpal, P., et al. (2012). Arabidopsis SMALL AUXIN UP RNA63 promotes hypocotyl and stamen filament elongation. Plant J. 71, 684-697. doi: 10.1111/j.1365313X.2012.05024.X

Cheng, Y., Dai, X., and Zhao, Y. (2006). Auxin biosynthesis by the YUCCA flavin monooxygenases controls the formation of floral organs and vascular tissues in Arabidopsis. Genes Dev. 20, 1790-1799. doi: 10.1101/gad.1415106

Christensen, S. K., Dagenais, N., Chory, J., and Weigel, D. (2000). Regulation of auxin response by the protein kinase PINOID. Cell 100, 469-478. doi: 10.1016/S0092-8674(00)80682-0

Cui, D., Zhao, J., Jing, Y., Fan, M., Liu, J., Wang, Z., et al. (2013). The Arabidopsis IDD14, IDD15, and IDD16 cooperatively regulate lateral organ morphogenesis and gravitropism by promoting auxin biosynthesis and transport. PLOS Genetics 9:e1003759. doi: 10.1371/journal.pgen.1003759

Dal Bosco, C., Dovzhenko, A., Liu, X., Woerner, N., Rensch, T., Eismann, M., et al. (2012a). The endoplasmic reticulum localized PIN8 is a pollen-specific auxin carrier involved in intracellular auxin homeostasis. Plant J. 71, 860-870. doi: 10.1111/j.1365-313X.2012.05037.x

Dal Bosco, C., Dovzhenko, A., and Palme, K. (2012b). Intracellular auxin transport in pollen PIN8, PIN5 and PILS5. Plant Signal. Behav. 7, 1504-1505. doi: $10.4161 /$ psb. 21953

Ding, Z., Wang, B., Moreno, I., Dupláková, N., Simon, S., Carraro, N., et al. (2012). ER-localized auxin transporter PIN8 regulates auxin homeostasis and male gametophyte development in Arabidopsis. Nat. Commun. 3:941. doi: 10.1038/ncomms 1941

Ellis, C. M., Nagpal, P., Young, J. C., Hagen, G., Guilfoyle, T. J., and Reed, J. W. (2005). AUXIN RESPONSE FACTOR1 and AUXIN RESPONSE FACTOR2 regulate senescence and floral organ abscission in Arabidopsis thaliana. Development 132, 4563-4574. doi: 10.1242/dev.02012

Esau, K. (1977). Anatomy of Seed Plants, 2nd Edn. New York, NY: Wiley.

Expósito-Rodríguez, M., Borges, A. A., Borges-Pérez, A., Hernández, M., and Pérez, J. A. (2007). Cloning and biochemical characterisation of ToFZY, a tomato gene encoding a flavin monooxygenase involved in a tryptophan -dependent auxin biosynthesis pathway. J. Plant Growth Regul. 26, 329-340. doi: 10.1007/s00344007-9019-2

Feng, X., and Dickinson, H. G. (2010). Tapetal cell fate, lineage and proliferation in the Arabidopsis anther. Development 137, 2409-2416. doi: 10.1242/dev.049320

Feng, X. L., Ni, W. M., Elge, S., Mueller-Roeber, B., Xu, Z. H., and Xue, H. W. (2006). Auxin flow in anther filaments is critical for pollen grain development through regulating pollen mitosis. Plant Mol. Biol. 61, 215-226. doi: 10.1007/s11103-006-0005-Z

Forestan, C., and Varotto, S. (2012). The role of PIN auxin efflux carriers in polar auxin transport and accumulation and their effect on shaping maize development. Mol. Plant. 5, 787-798. doi: 10.1093/mp/ssr103

Forestan, C., Farinati, S., and Varotto, S. (2012). The maize PIN gene family of auxin transporters. Front. Plant Sci. 3:16. doi: 10.3389/fpls.2012.00016

Friml, J. (2010). Subcellular trafficking of PIN auxin efflux carriers in auxin transport. Eur. J. Cell Biol. 89, 231-235. doi: 10.1016/j.ejcb.2009.11.003

Friml, J., Vieten, A., Sauer, M., Weijers, D., Schwarz, H., Hamann, T., et al. (2003). Efflux-dependent auxin gradients establish the apical-basal axis of Arabidopsis. Nature 426, 147-153. doi: 10.1038/nature02085

Furutani, M., Kajiwara, T., Kato, T., Treml, B. S., Stockum, C., Torres-Ruiz, R. A., et al. (2007). The gene MACCHI-BOU 4/ENHANCER OF PINOID encodes a NPH3-like protein and reveals similarities between organogenesis and phototropism at the molecular level. Development 134, 3849-3859. doi: 10.1242/dev.009654

Furutani, M., Vernoux, T., Traas, J., Kato, T., Tasaka, M., and Aida, M. (2004) PIN-FORMED1 and PINOID regulate boundary formation and cotyledon development in Arabidopsis embryogenesis. Development 131, 5021-5030. doi: 10.1242/dev.01388

Gallavotti, A., Barazesh, S., Malcomber, S., Hall, D., Jackson, D., Schmidt, R. J., et al. (2008b). sparse inflorescencel encodes a monocot-specific YUCCA-like gene required for vegetative and reproductive development in maize. Proc. Natl. Acad. Sci. U.S.A. 105, 15196-15201. doi: 10.1073/pnas.0805596105

Gallavotti, A., Yang, Y., Schmidt, R. J., and Jackson, D. (2008a). The Relationship between auxin transport and maize branching. Plant Physiol. 147, 1913-1923. doi: 10.1104/pp.108.121541

Gälweiler, L., Guan, C., Müller, A., Wisman, E., Mendgen, K., Yephremov, A., et al. (1998). Regulation of polar auxin transport by AtPIN1 in Arabidopsis vascular tissue. Science 282, 2226-2230. doi: 10.1126/science.282.5397.2226

Garrett, J. J. T., Meents, M. J., Blackshaw, M. T., Blackshaw, L. C., Hou, H., Styranko, D. M., et al. (2012). A novel, semi-dominant allele of MONOPTEROS provides insight into leaf initiation and vein pattern formation. Planta 236, 297-312. doi: 10.1007/s00425-012-1607-0

Geisler, M., and Murphy, A.S. (2006). The ABC of auxin transport: the role of p-glycoproteins in plant development. FEBS Lett. 580, 1094-1102. doi: 10.1016/j.febslet.2005.11.054

Girin, T., Paicu, T., Sephenson, P., Fuentes, S., Körner, E., O’Brien, M., et al. (2011). INDEHISCENT and SPATULA interact to specify carpel and valve margin tissue and thus promote seed dispersal in Arabidopsis. Plant Cell 23, 3641-3653. doi: 10.1105/tpc.111.090944 
Goldberg, R. B., Beals, T. P., and Sanders, P. M. (1993). Anther development: basic principles and practical applications. Plant Cell 5, 1217-1229. doi: $10.1105 /$ tpc.5.10.1217

Honys, D., and Twell, D. (2004). Transcriptome analysis of haploid male gametophyte development in Arabidopsis. Genome Biol. 5:R85. doi: 10.1186/gb-2004-511-r85

Ito, T., Ng, K. H., Lim, T. S., Yu, H., and Meyerowitz, E. M. (2007). The homeotic protein AGAMOUS controls late stamen development by regulating a jasmonate biosynthetic gene in arabidopsis. Plant Cell 19, 3516-3529. doi: 10.1105/tpc.107.055467

Jia, G., Liu, X., Owen, H. A., and Zhao, D. (2008). Signaling of cell fate determination by the TPD1 small protein and EMS1 receptor kinase. Proc. Natl. Acad. Sci. U.S.A. 105, 2220-2225. doi: 10.1073/pnas.0708795105

Kim, S. Y., Xu, Z. Y., Song, K., Kim, D. H., Kang, H., Reichardt, I., et al. (2013). Adaptor protein complex 2-mediated endocytosis is crucial for male reproductive organ development in Arabidopsis. Plant Cell 25, 2970-2985. doi: $10.1105 /$ tpc. 113.114264

Knöller, A. S., Blakeslee, J. J., Richards, E. L., Peer, W. A., and Murphy, A. S. (2010). Brachytic2/ZmABCB1 functions in IAA export from intercalary meristems. J. Exp. Bot. 61, 3689-3696. doi: 10.1093/jxb/erq180

Krizek, B. A. (2011). Auxin regulation of Arabidopsis flower development involves members of the AINTEGUMENTA-LIKE/PLETHORA (AIL/PLT) family. J. Exp. Bot. 62, 3311-3319. doi: 10.1093/jxb/err127

Ma, H. (2005). Molecular genetic analyses of microprogenesis and microgametogenesis in flowering plants. Annu. Rev. Plant Biol. 56, 393-434. doi: 10.1146/annurev.arplant.55.031903.141717

Madishetty, K., Bauer, P., Sharada, M. S., Al-Hammadi, A. S., and Sharma, R. (2006). Genetic characterization of the polycotyledon locus in tomato. Theor. Appl. Genet. 113, 673-683. doi: 10.1007/s00122-006-0332-0

McSteen, P., and Hake, S. (2001). barren inflorescence2 regulates axillary meristem development in the maize inflorescence. Development 128, 2881-2891. doi: 10.1104/pp.107.098558

Michniewicz, M., Zago, M. K., Abas, L., Weijers, D., Schweighofer, A., Meskiene, I., et al. (2007). Antagonistic regulation of PIN phosphorylation by PP2A and PINOID directs auxin flux. Cell 130, 1044-1056. doi: 10.1016/j.cell.2007. 07.033

Morita, Y., and Kyozuka, J. (2007). Characterization of OsPID, the rice ortholog of PINOID, and its possible involvement in the control of polar auxin transport. Plant Cell Physiol. 48, 540-549. doi: 10.1093/pcp/pcm024

Mounet, F., Moing, A., Kowalczyk, M., Rohrmann, J., Petit, J., Garcia, V., et al. (2012). Down-regulation of a single auxin efflux transport protein in tomato induces precocious fruit development. J. Exp. Bot. 13, 4901-4917. doi: 10.1093/jxb/ers 167

Mravec, J., Skùpa, P., Bailly, A., Hoyerová, K., Křeček, P., Bielach, A., et al. (2009). Subcellular homeostasis of phytohormone auxin is mediated by the ERlocalized PIN5 transporter. Nature 459, 1136-1140. doi: 10.1038/nature08066

Murmu, J., Bush, M. J., DeLong, C., Li, S., Xu, M., Khan, M., et al. (2010). Arabidopsis basic leucine-zipper transcription factors TGA9 and TGA10 interact with floral glutaredoxins ROXY1 and ROXY2 and are redundantly required for anther development. Plant Physiol. 154, 1492-1504. doi: 10.1104/pp.110. 159111

Nagpal, P., Ellis, C. M., Weber, H., Ploense, S. E., Barkawi, L. S., Guilfoyle, T. J., et al. (2005). Auxin response factors ARF6 and ARF8 promote jasmonic acid production and flower maturation. Development 132, 4107-4118. doi: 10.1242/dev.01955

Nishimura, T., and Koshiba, T. (2010). Auxin biosynthesis site and polar transport in maize coleoptiles. Plant Signal. Behav. 5, 573-575. doi: 10.4161/psb.11493

Noh, B., Murphy, A. S., and Spalding, E. P. (2001). Multidrug resistance-like genes of arabidopsis required for auxin transport and auxin-mediated development. Plant Cell 13, 2441-2454. doi: 10.1105/tpc.010350

O’Connor, D. L., Runions, A., Sluis, A., Bragg, J., Vogel, J. P., Prusinkiewicz, P., et al. (2014). A division in PIN-mediated auxin patterning during organ initiation in grasses. PLoS Comput. Biol. 10:e1003447. doi: 10.1371/journal.pcbi.1003447

Okada, K., Ueda, J., Komaki, M. K., Bell, C. J., and Shimura, Y. (1991). Requirement of the auxin polar transport system in early stages of Arabidopsis floral bud formation. Plant Cell 3, 677-684. doi: 10.1105/tpc.3.7.677

Pacini, E., Franchi, G. G., and Hesse, M. (1985). The tapetum: its form, function, and possible phylogeny in Embryophyta. Plant Syst. Evol. 149, 155-185. doi: 10.1007/BF00983304
Paponov, I. A., Teale, W. D., Trebar, M., Blilou, K., and Palme, K. (2005). The PIN auxin efflux facilitators: evolutionary and functional perspectives. Trends Plant Sci. 10, 170-177. doi: 10.1016/j.tplants.2005.02.009

Parry, G., and Estelle, M. (2006). Auxin receptors: a new role for F-box proteins. Curr. Opin. Cell Biol. 18, 152-156. doi: 10.1016/j.ceb.2006.02.001

Peer, W. A., Blakeslee, J. J., Yang, H., and Murphy, A. S. (2011). Seven things we think we know about auxin transport. Mol. Plant 4, 487-504. doi: $10.1093 / \mathrm{mp} / \mathrm{ssr} 034$

Peng, J., and Chen, R. (2011). Auxin efflux transporter MtPIN10 regulates compound leaf and flower development in Medicago truncatula. Plant Signal. Behav. 6, 1537-1544. doi: 10.4161/psb.6.10.17326

Pina, C., Pinto, F., Feijó, J. A., and Becker, J. D. (2005). Gene family analysis of the Arabidopsis pollen transcriptome reveals biological implications for cell growth, division control, and gene expression regulation. Plant Physiol. 138, 744-756. doi: 10.1104/pp.104.057935

Przemeck, G. K. H., Mattsson, J., Hardtke, C. S., Sung, Z. R., and Berleth, T. (1996). Studies on the role of the Arabidopsis gene MONOPTEROS in vascular development and plant axialization. Planta 200, 229-237. doi: 10.1007/ BF00208313

Reinhardt, D., Mandel, T., and Kuhlemeier, C. (2000). Auxin regulates the initiation and radial position of plant lateral organs. Plant Cell 12, 507-518. doi: 10.1105/tpc.12.4.507

Reinhardt, D., Pesce, E. R., Stieger, P., Mandel, T., Baltensperger, K., Bennett, M., et al. (2003). Regulation of phyllotaxis by polar auxin transport. Nature 426, 255-260. doi: 10.1038/nature02081

Ren, Z., Li, Z., Miao, Q., Yang, Y., Deng, W., and Hao, Y. (2011). The auxin receptor homologue in Solanum lycopersicum stimulates tomato fruit set and leaf morphogenesis. J. Exp. Bot. 62, 2815-2826. doi: 10.1093/jxb/erq455

Sanders, P. M., Bui, A. Q., Weterings, K., McIntire, K. N., Hsu, Y. C., Lee, P. Y., et al. (1999). Anther developmental defects in Arabidopsis thaliana male-sterile mutants. Sex. Plant Reprod. 11, 297-322. doi: 10.1007/s004970050158

Sanders, P. M., Lee, P. Y., Biesgen, C., Boone, J. D., Beals, T. P., Weiler, E. W., et al. (2000). The arabidopsis DELAYED DEHISCENCE1 gene encodes an enzyme in the jasmonic acid synthesis pathway. Plant Cell 12, 1041-1062. doi: 10.1105/tpc.12.7.1041

Sazuka, T., Kamiya, N., Nishimura, T., Ohmae, K., Sato, Y., Imamura, K., et al. (2009). A rice tryptophan deficient dwarf mutant, tdd 1 , contains a reduced level of indole acetic acid and develops abnormal flowers and organless embryos. Plant J. 60, 227-241. doi: 10.1111/j.1365-313X.2009.03952.x

Schnabel, E. L., and Frugoli, J. (2004). The PIN and LAX families of auxin transport genes in Medicago truncatula. Mol. Genet. Genomics 272, 420-432. doi: 10.1007/s00438-004-1057-x

Schruff, M. C., Spielman, M., Tiwari, S., Adams, S., Fenby, N., and Scott, R. J. (2006). The AUXIN RESPONSE FACTOR 2 gene of Arabidopsis links auxin signalling, cell division, and the size of seeds and other organs. Development 133, 251-261. doi: 10.1242/dev.02194

Scott, R. J., Spielman, M., and Dickinson, H. G. (2004). Stamen structure and function. Plant Cell 16, S46-S60. doi: 10.1105/tpc.017012

Sessions, A., Nemhauser, J. L., McColl, A., Roe, J. L., Feldmann, K. A., and Zambryski, P. C. (1997). ETTIN patterns the Arabidopsis floral meristem and reproductive organs. Development 124, 4481-4491. doi: 10.3732/ajb. 89.4.559

Shen, C., Bai, Y., Wang, S., Zhang, S., Wu, Y., Chen, M., et al. (2010). Expression profile of PIN, AUX/LAX and PGP auxin transporter gene families in Sorghum bicolor under phytohormone and abiotic stress. FEBS J. 277, 2954-2969. doi: 10.1111/j.1742-4658.2010.07706.x

Smyth, D. R., Bowman, J. L., and Meyerowitz, E. M. (1990). Early flower development in Arabidopsis. Plant Cell 2, 755-767. doi: 10.1105/tpc.2.8.755

Smyth, D. R. (2010). “Stamens," in eLS (Chichester: John Wiley \& Sons Ltd.). doi: 10.1002/9780470015902.a0002066.pub2. Available online at: http://www.els.net

Ståldal, V., Cierlik, I., Chen, S., Landberg, K., Baylis, T., Myrenas, M., et al. (2012). The Arabidopsis thaliana transcriptional activator STYLISH1 regulates genes affecting stamen development, cell expansion and timing of flowering. Plant Mol. Biol. 78, 545-559. doi: 10.1007/s11103-012-9888-z

Swarup, R., and Péret, B. (2012). AUX/LAX family of auxin influx carriers-an overview. Front. Plant Sci. 3:225. doi: 10.3389/fpls.2012.00225

Takada, S., Hibara, K., Ishida, T., and Tasaka, M. (2001). The CUP-SHAPED COTYLEDON1 gene of Arabidopsis regulates shoot apical meristem formation. Development 128, 1127-1135. doi: 10.1093/pcp/pcg038 
Thomson, K. S., Hertel, R., Muller, S., and Tavares, J. E. (1973). 1-NNaphthylphthalamic acid and 2,3,5-triiodobenzoic acid-in-vitro binding to particulate cell fractions and action on auxin transport in corn coleoptiles. Planta 109, 337-352. doi: 10.1007/BF00387102

Titapiwatanakun, B., Blakeslee, J. J., Bandyopadhyay, A., Yang, H., Mravec, J., Sauer, M., et al. (2008). ABCB19/PGP19 stabilises PIN1 in membrane microdomains in Arabidopsis. Plant J. 57, 27-44. doi: 10.1111/j.1365-313X.2008.03668.x

Titapiwatanakun, B., and Murphy, A. S. (2009). Post-transcriptional regulation of auxin transport proteins: cellular trafficking, protein phosphorylation, protein maturation, ubiquitination, and membrane composition. J. Exp. Bot. 60, 1093-1107. doi: 10.1093/jxb/ern240

Tivendale, N. D., Davies, N. W., Molesworth, P. P., Davidson, S. E., Smith, J. A., Lowe, E. K., et al. (2010). Reassessing the role of N-hydroxytryptamine in auxin biosynthesis. Plant Physiol. 154, 1957-1965. doi: 10.1104/pp.110.165803

Treml, B. S., Winderl, S., Radykewicz, R., Herz, M., Schweizer, G., Hutzler, P., et al. (2005). The gene ENHANCER OF PINOID controls cotyledon development in the Arabidopsis embryo. Development 132, 4063-4074. doi: 10.1242/dev.01969

Ulmasov, T., Murfett, J., Hagen, G., and Guilfoyle, T. J. (1997). Aux/IAA proteins repress expression of reporter genes containing natural and highly active synthetic auxin response elements. Plant Cell 9, 1963-1971. doi: 10.1105/tpc.9.11.1963

van Mourik, S., Kaufmann, K., van Dijk, A. D. J., Angenent, G. C., Merks, R. M. H., and Molenaar, J. (2012). Simulation of organ patterning on the floral meristem using a polar auxin transport model. PLoS ONE 7:e28762. doi: 10.1371/journal.pone.0028762

Wabnik, K., Kleine-Vehn, J., Govaerts, W., and Friml, J. (2011). Prototype cell-tocell auxin transport mechanism by intracellular auxin compartmentalization. Trends Plant Sci. 16, 468-475. doi: 10.1016/j.tplants.2011.05.002

Wang, H., Jones, B., Li, Z., Frasse, P., Delalande, C., Regad, F., et al. (2005). The tomato aux/IAA transcription factor IAA9 Is involved in fruit development and leaf morphogenesis. Plant Cell 17, 2676-2692. doi: 10.1105/tpc.105.033415

Wang, Y., Zhang, W. Z., Song, L. F., Zou, J. J., Su, Z., and Wu, W. H. (2008). Transcriptome analyses show changes in gene expression to accompany pollen germination and tube growth in Arabidopsis. Plant Physiol. 148, 1201-1211. doi: $10.1104 /$ pp.108.126375

Wellmer, F., Graciet, E., and Riechmann, J. L. (2013). Specification of floral organs in Arabidopsis. J. Exp. Bot. 65, 1-9. doi: 10.1093/jxb/ert385

Whipple, C. J., Ciceri, P., Padilla, C. M., Ambrose, B. A., Bandong, S. L., and Schmidt, R. J. (2004). Conservation of B-class floral homeotic gene function between maize and Arabidopsis. Development 131, 6083-6091. doi: 10.1242/dev. 01523

Wilson, Z. A., Song, J., Taylor, B., and Yang, C. (2011). The final split: the regulation of anther dehiscence. J. Exp. Bot. 62, 1633-1649. doi: 10.1093/jxb/err014
$\mathrm{Wu}, \mathrm{X}$., and McSteen, P. (2007). The role of auxin transport during inflorescence development in maize (Zea mays, Poaceae). Am. J. Bot. 94, 1745-1755. doi: 10.3732/ajb.94.11.1745

Xu, M., Zhu, L., Shou, H., and Wu, P. (2005). A PIN1 family gene, OsPIN1, involved in auxin-dependent adventitious root emergence and tillering in rice. Plant Cell Physiol. 46, 1674-1681. doi: 10.1093/pcp/pcil83

Yamamoto, Y., Kamiya, N., Morinaka, Y., Matsuoka, M., and Sazuka, T. (2007). Auxin biosynthesis by the YUCCA genes in rice. Plant Physiol. 143, 1362-1371. doi: 10.1104/pp.106.091561

Yang, J., Tian, L., Sun, M. X., Huang, X. Y., Zhu, J., Guan, Y. Y., et al. (2013). Auxin Response Factor17 is essential for pollen wall pattern formation in Arabidopsis. Plant Physiol. 162, 720-731. doi: 10.1104/pp.113.214940

Zažímalová, E., Murphy, A. S., Yang, H., Hoyerová, K., and Hošek, P. (2010). Auxin transporters-why so many? Cold Spring Harb. Perspect. Biol. 2:a001552. doi: 10.1101/cshperspect.a001552

Zhang, Q., Li, J., Zhang, W., Yan, S., Wang, R., Zhao, J., et al. (2012). The putative auxin efflux carrier OsPIN3t is involved in the drought stress response and drought tolerance. Plant J. 72, 805-816. doi: 10.1111/j.1365-313X.2012. 05121.x

Zhao, Y. (2012). Auxin biosynthesis: a simple two-step pathway converts tryptophan to indole-3-acetic acid in plants. Mol. Plant 5, 334-338. doi: $10.1093 / \mathrm{mp} / \mathrm{ssr} 104$

Zhou, C., Han, L., and Wang, Z. Y. (2011). Potential but limited redundant roles of MtPIN4, MtPIN5 and MtPIN10/SLM1 in the development of Medicago truncatula. Plant Signal. Behav. 6, 1doi: 10.4161/psb.6.11.17508

Conflict of Interest Statement: The authors declare that the research was conducted in the absence of any commercial or financial relationships that could be construed as a potential conflict of interest.

Received: 28 April 2014; paper pending published: 05 June 2014; accepted: 24 June 2014; published online: 16 July 2014.

Citation: Cardarelli M and Cecchetti V (2014) Auxin polar transport in stamen formation and development: how many actors? Front. Plant Sci. 5:333. doi: 10.3389/fpls. 2014.00333

This article was submitted to Plant Evolution and Development, a section of the journal Frontiers in Plant Science.

Copyright (C) 2014 Cardarelli and Cecchetti. This is an open-access article distributed under the terms of the Creative Commons Attribution License (CC BY). The use, distribution or reproduction in other forums is permitted, provided the original author(s) or licensor are credited and that the original publication in this journal is cited, in accordance with accepted academic practice. No use, distribution or reproduction is permitted which does not comply with these terms. 